\title{
Determination of minimal duration necessary for the isolation of humic acid contained in composted pineapple leaves
}

Osumanu H. AHMED*

Department of Land Management, Faculty of Agriculture, University Putra Malaysia, 43400 UPM, Serdang, Selangor, Malaysia osman60@hotmail.com
${ }^{*}$ Correspondence and reprints

Fruits, 2005 , vol. 60 , p. $115-120$ (C) 2005 Cirad/EDP Sciences All rights reserved DOI: 10.1051/fruits:2005022

RESUMEN ESPAÑOL, p. 120

\section{Determination of minimal duration necessary for the isolation of humic acid contained in composted pineapple leaves.}

Abstract - Introduction. The isolation of humic acid (Ha) from decomposed organic substances such as compost is time-consuming, as it takes not less than $24 \mathrm{~h}$. We investigated whether the isolation time of Ha produced from composted pineapple leaves could be reduced. Materials and methods. $\mathrm{Ha}$ from $10 \mathrm{~g}$ of pineapple compost was extracted with $100 \mathrm{~mL}$ of $0.10 \mathrm{M} \mathrm{NaOH}$. Different extraction times $[(4,8,12,16,20$ and 24) h] were tested. At the end of each time, the samples were centrifuged. The dark-colored supernatant liquor containing $\mathrm{Ha}$ was decanted and filtered; the $\mathrm{pH}$ of the solution was adjusted to 1.0. After acidification, the fractionation times tested were $(3,6,9,12,15,18,21$ and 24) h. At the end of each fractionation time, the supernatant liquor (fulvic acid) was siphoned off from the acidified extract. The remainder of the suspension was transferred to a polyethylene bottle. Ha was purified by suspending it in $50 \mathrm{~mL}$ distilled water, then centrifuged, and the supernatant was decanted. After repeating this procedure five times, the supernatant and the fulvic acid were analyzed for $\mathrm{Ca}, \mathrm{K}, \mathrm{Mg}, \mathrm{Mn}, \mathrm{Na}, \mathrm{Cu}, \mathrm{Fe}$ and $\mathrm{Zn}$. The washed $\mathrm{Ha}$ was oven dried at $30{ }^{\circ} \mathrm{C}$ to a constant weight and the Ha samples were analyzed for ash and mineral matter. Results and discussion. The ash content was not more than $1 \%$, the generally acceptable maximum value. The mineral contents decreased in Ha samples with washing. The yield of Ha significantly increased with increasing extraction time, except for the (20 and 24) h extraction times, which did not show statistically different Ha yield, meaning that the exchange sites of Ha of the pineapple compost might have been saturated with Na ions from $20 \mathrm{~h}$. There was no significant difference among the fractionation times, indicating that Ha of the pineapple compost requires about $3 \mathrm{~h}$ to equilibrate or stand immediately after acidification for the $\mathrm{H}$ ions to replace the $\mathrm{Na}$ and the other cations. There was no significant interaction between the factors extraction and fractionation. Conclusion. The isolation of humic acids from composted pineapple leaves can be achieved with an extraction time of $20 \mathrm{~h}$ and a fractionation time of $3 \mathrm{~h}$.

Malaysia / Ananas comosus / waste utilization / composting / composts / humic acids / methods

Détermination du temps minimal nécessaire à l'isolement de l'acide humique contenu dans du compost de feuilles d'ananas.

Résumé - Introduction. L'isolement de l'acide humique (Ah) dans des substances organiques décomposées tel que du compost prend du temps, car il nécessite au moins $24 \mathrm{~h}$. Nous avons cherché si le temps nécessaire à l'isolement d'Ah produit à partir de feuilles d'ananas compostées pouvait être réduit. Matériel et méthodes. L'extraction d'Ah à partir du compost de feuilles d'ananas a été effectuée à partir de $10 \mathrm{~g}$ de compost dans $100 \mathrm{ML}$ de $\mathrm{NaOH}$ 0,10 M. Différents temps d'extraction [(4, $8,12,16,20$, et 24) h] ont été testés. À la fin de chaque temps, les échantillons ont été centrifugés. Le liquide sombre surnageant contenant l'Ah a été décanté et filtrée ; le pH de la solution a été ajusté à 1 . Après cette acidification, les temps de fractionnement testés ont été de $(3,6,9,12,15,18,21$ et 24) hà température ambiante. À la fin de chaque temps de fractionnement, le liquide surnageant (acide fulvique) a été récupéré de l'extrait acidifié. Le reste de la suspension a été transféré en bouteilles de polyéthylène. L'Ah a été purifié en le reprenant dans $50 \mathrm{~mL}$ d'eau distillée, puis centrifugé ; le surnageant a été décanté. Après avoir répété cinq fois cette procédure, l'acide fulvique et le surnageant ont été analysés pour déterminer les teneurs en $\mathrm{Ca}, \mathrm{K}, \mathrm{Mg}, \mathrm{Mn}, \mathrm{Na}, \mathrm{Cu}$, Fe et $\mathrm{Zn}$. L'Ah lavé a été séché au four à $30^{\circ} \mathrm{C}$ à un poids constant et les échantillons ont été analysés pour évaluer leur teneur en cendres et en matière minérale. Résultats et discussion. La teneur en cendres n'a pas dépassé 1\%, seuil généralement acceptable. Les teneurs minérales du surnageant ont diminué avec le lavage des échantillons. Le rendement en Ah a augmenté de manière significative avec le temps d'extraction, excepté pour les périodes de (20 et 24) h qui n'ont pas montré de différences significatives de rendement en Ah ; cela signifierait que les sites d'échange de l'Ah extrait du compost d'ananas pourraient avoir été saturés avec des ions de Na à partir d'un temps d'extraction de $20 \mathrm{~h}$. Il n'y a eu aucune différence significative entre les temps de fractionnement testés ; cela indiquerait que, après acidification, l'Ah du compost d'ananas exigerait environ $3 \mathrm{~h}$ pour que les ions de $\mathrm{H}$ remplacent ceux de Na et des autres cations. Il n'y a eu aucune interaction significative entre les facteurs extraction et fractionnement. Conclusion. L'isolement d'acide humique à partir du compost de feuilles d'ananas peut être réalisé avec un temps d'extraction de $20 \mathrm{~h}$ et un temps de fractionnement de $3 \mathrm{~h}$.

Malaisie / Ananas comosus / utilisation des déchets / compostage / compost acide humique / méthode 


\section{Introduction}

Humic substances arise from the chemical and biological degradation of plant and animal residues, and from the synthetic activities of microorganisms. As a fraction of humic substances, humic acids play a major role in soil cation exchange capacity, complexation of heavy metal ions and pesticides [1], soil conditioning (sprinkling of $0.05 \mathrm{~g}$ of humic acids per $\mathrm{kg}$ of loamy soil reduces runoff time and soil loss by runoff by $36 \%$ ), and plant growth and development [2, 3]. Recently, calcium and potassium humates of humic acids that can serve as liming agent and organic-based potassium fertilizer, respectively, have been produced $[4,5]$.

Agricultural waste such as pineapple residues (e.g., depending on the purity of the extracting, composted pineapple leaves contain 20-30\% humic acids [6], which when well composted can be rich in humic acids) are recycled in most developing countries by open burning before subsequent planting. For instance, approximately $13 \mathrm{t} \cdot \mathrm{ha}^{-1}$ of pineapple residue are produced every growing season on peat soil in Malaysia, but, in the absence of an effective and efficient way of recycling these residues, it is openly burned in situ before replanting. Due to the $1997 / 1998$ haze and fire catastrophe in Southeast Asia that caused an economic loss of US\$ 4.085 billion in Indonesia [7], US\$ 321 million in Malaysia [8], and US\$ 69.3 million in Singapore [9], this kind of residue management practice has raised concern. To discourage burning, K-humate (salt of humic acids), an organically based $\mathrm{K}$ fertilizer containing 38\% K composted pineapple leaves, has been successfully produced [5].

Although the time-consuming ( 2 to 7 days) purification method of humic acids $[10,11]$ has recently been reduced to 1 day [12], the isolation time of these acids is still long as the extraction time alone ranges between $4 \mathrm{~h}$ (minimum) and $48 \mathrm{~h}[1,13,14]$ even though an extraction time of $24 \mathrm{~h} \mathrm{[15-17]} \mathrm{is}$ the usual practice. Besides, fractionation time ranges between (12 and 24) h [1, 14, 17], although most studies usually use $24 \mathrm{~h}$. To facilitate the humic acid and K-humate production and the use from crop residues as well as to contribute to the reduction of environmental pollution through burning, the objective of the study was to investigate whether the isolation time of humic acids produced from composted pineapple leaves could be reduced or not.

\section{Materials and methods}

Composted pineapple leaves with typical compost characteristics produced in one of our studies [5] were used: cation exchange capacity $=68.30 \mathrm{cmol} \cdot \mathrm{kg}^{-1},[\mathrm{C} / \mathrm{N}]$ ratio $=$ 11.58 , ash $=23.00 \%$. The elemental composition and the dominant functional groups of the humic acids in this compost were the same as already published [6].

The extraction of humic acids (three replicates) was done using the method described by Stevenson [1] with some modifications. Ten $g$ (dry-weight basis) of compost (at natural moisture level) was placed in polyethylene centrifuge bottles, $100 \mathrm{~mL} \mathrm{NaOH}(0.01 \mathrm{M})$ [18] solution was added and the bottles were tightly closed with a rubber stopper. The samples were equilibrated at room temperature (about $25^{\circ} \mathrm{C}$ ) on a reciprocal mechanical shaker. The extraction (shaking) times used were $4 \mathrm{~h}\left(\mathrm{Et}_{4}\right), 8 \mathrm{~h}\left(\mathrm{Et}_{8}\right), 12 \mathrm{~h}\left(\mathrm{Et}_{12}\right)$, $16 \mathrm{~h}\left(\mathrm{Et}_{16}\right), 20 \mathrm{~h}\left(\mathrm{Et}_{20}\right)$ and $24 \mathrm{~h}\left(\mathrm{Et}_{24}\right)$. At the end of each extraction time, the sides of the bottles were washed with distilled water, and the mixture centrifuged at $7500 \mathrm{rpm}$ for $12 \mathrm{~min}$. The dark-colored supernatant liquors containing the humic acids were decanted, filtered through glass-wool, and the $\mathrm{pH}$ of the solutions was adjusted to 1.0 with $6 \mathrm{~N}$ $\mathrm{HCl}$. The humic acids were allowed to stand or equilibrate at room temperature

The experiment was carried out under $\mathrm{N}_{2}$ gas (fluxing the polyethylene centrifuge bottles with $\mathrm{N}_{2}$ gas) so as to minimize chemical changes in the extracted organic matter. The fractionation times used immediately after acidification were $3 \mathrm{~h}\left(\mathrm{Ft}_{3}\right), 6 \mathrm{~h}\left(\mathrm{Ft}_{6}\right)$, $9 \mathrm{~h}\left(\mathrm{Ft}_{0}\right), 12 \mathrm{~h}\left(\mathrm{Ft}_{12}\right), 15 \mathrm{~h}\left(\mathrm{Ft}_{15}\right), 18 \mathrm{~h}\left(\mathrm{Ft}_{18}\right)$, $21 \mathrm{~h}\left(\mathrm{Ft}_{21}\right)$ and $24 \mathrm{~h}\left(\mathrm{Ft}_{24}\right)$. At the end of each equilibration, the supernatant liquors (fulvic acid) [19] were siphoned off from the acidified extract. The remainders of the suspensions were transferred to polyethylene bottles, and the humic acids were centrifuged. The method described by Ahmed 
Table I.

Ranges of the elemental concentrations $\left(\mathrm{mg} \cdot \mathrm{L}^{-1}\right)$ in the supernatant solutions before and after washing of compost samples when extracting humic acid from composted pineapple leaves.

$\begin{array}{lcccccccc}\text { Treatment } & \mathrm{K} & \mathrm{Ca} & \mathrm{Na} & \mathrm{Mg} & \mathrm{Fe} & \mathrm{Zn} & \mathrm{Mn} & \mathrm{Cu} \\ \text { Before washing } & 83.27-130.63 & 29.57-59.62 & 20.84-26.55 & 16.74-35.76 & 6.26-9.76 & 6.13-7.79 & 2.49-3.08 & 0.12-0.18 \\ \text { After washing } & 8.02-13.37 & 0.19-0.47 & 3.48-7.97 & 0.20-0.78 & 0.01-1.23 & 0.01-0.08 & 0-0.08 & 0-0.03\end{array}$

et al. [12] was used with modifications to purify the humic acids.

The humic acids were purified by being suspended in $50 \mathrm{~mL}$ distilled water (excess distilled water can serve as Bronsted-Lowry acid), centrifuged at $7500 \mathrm{rpm}$ for $10 \mathrm{~min}$, and the supernatant was decanted. This procedure was repeated five times, after which the fifth supernatant and the fulvic acid were analyzed for $\mathrm{Ca}, \mathrm{K}, \mathrm{Na}, \mathrm{Mg}, \mathrm{Mn}, \mathrm{Cu}, \mathrm{Fe}$ and $\mathrm{Zn}$ using an atomic absorption spectrophotometer. The washed humic acids were oven dried at $30^{\circ} \mathrm{C}$ (no dry freezer available) to a constant weight. The humic acid samples were analyzed for ash by combusting them at $750{ }^{\circ} \mathrm{C}$ for $4 \mathrm{~h}[20]$.

The effect of extraction time, equilibration time after acidification, and the interaction between these two factors on the yield of humic acids were studied in a factorial manner. The data were analyzed using an analysis of variance method and means separated using Tukey's test. The statistical analysis system (SAS) version 8.2 was used for data analysis.

\section{Results and discussion}

When humic acids are extracted, they are usually not free from mineral matter [1]. For instance, an observation shows that the prominence of the $1740 \mathrm{~cm}^{-1}$ spectral band provides evidence of not dealing with a humate or the salt of humic acids, and one of the indicators of the purity of humic acids is the content of mineral matter or ash, which should generally be less than $1 \%$. The ash content of the humic acids was found to range between $(0.4$ and 0.5$) \%$, a range less than the generally accepted one, indicating that the humic acids in this study contained a relatively low content of inorganic ions. The relatively low ash content of the humic acids may be attributed to washing during purification as washing of the humic acids generally reduced the contents of $\mathrm{Ca}, \mathrm{K}, \mathrm{Na}$, $\mathrm{Mg}, \mathrm{Mn}, \mathrm{Cu}, \mathrm{Fe}$ and $\mathrm{Zn}$ (table I). The contents of these elements before washing the humic acids were generally high, but their contents decreased remarkably after washing (table I). This observation can be explained using the Bronsted-Lowry acid concept due to the fact that, besides removing the cations in solution, the excess distilled water used in the purification process might have served as Bonsted-Lowry acid, thereby donating more hydrogen ions that might have replaced some of the remaining $\mathrm{Ca}, \mathrm{K}, \mathrm{Na}, \mathrm{Mg}, \mathrm{Mn}, \mathrm{Cu}, \mathrm{Fe}$ and $\mathrm{Zn}$ at the exchange sites of the humic acids which were probably not replaced by hydrogen ions (during acidification) during the period of humic acid separation (precipitation) from the fulvic acid [12].

The humic acid yields of $\mathrm{Et}_{4}, \mathrm{Et}_{8}, \mathrm{Et}_{12}$, $\mathrm{Et}_{16}, \mathrm{Et}_{20}$ and $\mathrm{Et}_{24}$ were statistically different, but those of $\mathrm{Et}_{20}$ and $\mathrm{Et}_{24}$ were similar, indicating that the yield of humic acids increased with increasing extraction time from $\mathrm{Et}_{4}$ up to $\mathrm{Et}_{20}$ (table II). This observation can be partly attributed to the fact that the exchange sites of the humic acids of the pineapple compost need to be at some time saturated with $\mathrm{Na}$ ions, hence the difference in the yield with extraction time until between $\mathrm{Et}_{20}$ and $\mathrm{Et}_{24}$ when these sites seemed to have reached their saturation level. The yield of humic acids was not significantly affected by the duration of fractionation immediately after acidification. Because the yield of $\mathrm{Ft}_{3}$ was not statistically different from other treatments, it could be suggested that it takes 


\section{Table II.}

Humic acid yield (\%) in relation to the extraction time, equilibration time (fractionation) immediately after acidification of the compost samples and the interaction between the two factors, when extracting humic acid from composted pineapple leaves.

\begin{tabular}{|c|c|c|c|c|c|c|c|c|c|}
\hline \multirow[t]{2}{*}{$\begin{array}{l}\text { Extraction time } \\
\text { (h) }\end{array}$} & \multicolumn{8}{|c|}{$\begin{array}{l}\text { Fractionation time } \\
\text { (h) }\end{array}$} & \multirow[t]{2}{*}{ Mean } \\
\hline & 3 & 6 & 9 & 12 & 15 & 18 & 21 & 24 & \\
\hline 4 & 16.27 & 16.81 & 16.61 & 16.36 & 16.74 & 17.35 & 17.43 & 17.60 & $16.90 \mathrm{a}$ \\
\hline 8 & 20.53 & 20.35 & 21.15 & 21.47 & 21.01 & 21.12 & 21.00 & 20.74 & $20.92 b$ \\
\hline 12 & 21.37 & 21.74 & 21.47 & 21.05 & 21.27 & 22.00 & 21.95 & 21.89 & $21.59 \mathrm{c}$ \\
\hline 16 & 22.93 & 22.13 & 22.25 & 22.61 & 22.45 & 23.03 & 22.74 & 22.77 & $22.61 \mathrm{~d}$ \\
\hline 20 & 23.09 & 23.06 & 23.12 & 22.92 & 22.83 & 22.93 & 22.97 & 23.09 & $23.00 \mathrm{e}$ \\
\hline 24 & 23.42 & 22.79 & 23.23 & 23.01 & 23.02 & 22.70 & 23.12 & 23.03 & $23.04 \mathrm{e}$ \\
\hline Mean & 21.27 & 21.15 & 21.31 & 21.24 & 21.22 & 21.52 & 21.54 & 21.52 & - \\
\hline
\end{tabular}

Extraction time means followed by the same letter are not significantly different $(p=0.05)$ according toTukey's test.

about $3 \mathrm{~h}$ for the exchange sites of the humic acids of pineapple compost to be saturated with $\mathrm{H}$ ions after acidification. There was no significant interaction between extraction time and fractionation time, implying that the performances of all of the different fractionation times with any of the extraction times is the same: $3 \mathrm{~h}$ of equilibration after acidification is sufficient to displace the $\mathrm{Na}$ ions with $\mathrm{H}$ ions at the exchange sites of the humic acids. This could also mean that the effectiveness of fractionation was dependent on the duration of extraction. The adoption of an extraction time of $20 \mathrm{~h}$ or less and $3 \mathrm{~h}$ of fractionation implies that the isolation of humic acids of composted pineapple waste can be done within 1 day.

\section{Conclusions}

The yield of humic acids from composted pineapple leaves increases with an increasing period of extraction up to $20 \mathrm{~h}$. Immediately after acidification, fractionation time does not significantly affect the yield of humic acids from composted pineapple leaves but approximately $3 \mathrm{~h}$ are required to precipitate the humic acids of this compost. There was no significant interaction between these two factors. The time of iso- lating (extraction and fractionation) humic acids from composted pineapple leaves can be reduced by $24 \mathrm{~h}$. Through this work, the recycling of pineapple residues in the form of K-humate can be facilitated. This will help not only to discourage pineapple plantation owners from degrading the environment through open burning of pineapple residues, but it may also help to reduce the import bill of non-potassic fertilizer-producing countries such as Malaysia, where the import bill of these fertilizers is very high [21].

\section{References}

[1] Stevenson F.H., Humus chemistry: genesis, composition, reactions, 2nd ed., Wiley, New York, USA, 1994.

[2] Piccolo A., Pieramellara G., Bazzaoffi P., Pellegrini S., Evaluation of aggregate stability improvement following humic substances application to problem soil, in: Humic substances in the global environment and implication on human health, Elsevier Science, Amsterdam, The Netherlands, 1994, pp. 683688.

[3] Nardi S., Concheri G., Dell'Agnola G., Biological activity of humus, in: Humic substances in terrestrial ecosystems, Elsevier 
Science, Amsterdam, The Netherlands, 1994, pp. 361-406.

[4] Issa G., Peiris D., Patti A.F., Jackson W.R., Marshall M., Smith C.J., Coal derived humates for improving environmentally compromised soils, in: Humic substances downunder: understanding and managing organic matter in soils, sediments and water, Proc. 9th Int. Meet. Int. Humic Subst. Soc., Adel, Aust., 1998.

[5] Ahmed O.H., Husni M.H.A., Anuar A.R., Hanafi M.M., Alternative means of recycling pineapple leaf residues, Fruits 58 (1) (2003) 53-59.

[6] Ahmed, O.H., Husni M.H.A., Anuar A.R., Hanafi M.M., Production of humic acid from pineapple leaf residue, J. Sust. Agri. 22 (1) (2003) 111-124.

[7] Ruitenbeek J., Indonesia, in: Glover D., Jessup T., Indonesia's fires and haze: the catastrophe, Inst. Southeast Asia Stud., Singapore, 1999, pp. 86-112.

[8] Mohd Shahwahid H.O., Jamal O., Malaysia, in: Glover D., Jessup T., Indonesia's fires and haze: the catastrophe, Inst. Southeast Asia Stud., 1999, pp. 22-50.

[9] Hon P.M.L., Singapore, in: Glover D., Jessup T., Indonesia's fires and haze: the catastrophe, Inst. Southeast Asia Stud., Singapore, 1999, pp. 51-85.

[10] Siva K.B., Use of palm oil mill effluent (POME) and peat to reduce ammonia volatilisation from fertilizer urea, Univ. Putra Malaysia, thesis, Serdang, Malaysia, 1997.

[11] Husni M.H.A., Shanti D., Manas A.R., Anuar A.R., Shamshuddin J., Chemical variables affecting the lime requirement determination of tropical peat soils, Commun. Soil Sci. Plan. (13-14) (1995) 1211-2122.

[12] Ahmed O.H., Husni M.H.A., Anuar A.R., Hanafi M.M., Angela E.D.S., A modified way of producing humic acid from composted pineapple leaves, J. Sust. Agr. 25 (1) (2005) 129-139.
[13] Tan K.H., Soil sampling, preparation, and analysis, Marcel Dekker, Inc. New York, USA, 1996.

[14] Kakezawa M., Nishida T., Takahara Y., Structural characteristics of humic acids extracted from woody composts by twostep composting process, Soil Sci. Plant Nutr. 38 (1) (1992) 85-92.

[15] Amalfitano C., Quezada R.A., Wilson M.A., Hanna J.V., Chemical composition of humic acids: a comparison with precursor "light fraction" litter from different vegetations using spectroscopic techniques, Soil Sci. 159 (6) (1995) 391-401.

[16] Nobili M. de, Bragato G., Alcaniz J.M., Puigbo A., Comelllas L., Characterization of electrophoretic fractions of humic substances with different electrofocusing behaviour, Soil Sci. 150 (5) (1990) 763-770.

[17] Schnitzer M., Preston C.M., Analysis of humic acids by solution and solid- state carbon-13 nuclear magnetic resonance, Soil Sci. Soc. Am. J. 50 (1986) 326-331.

[18] Gracia D., Cegarra J., Bernal M. P., Navarro A., Comparative evaluation of methods employing alkali and sodium pyrophosphate to extract humic substances from peat, Commun. Soil Sci. Plan. 24 (13-14) (1993) 1481-1494.

[19] Aiken G.R., McKnight D.M., Wershaw R.L., MacCarthy P., An introduction to humic substances in soil, sediment, and water, in: Aiken G.R., MacKnight D.M., Wershaw R.L., MacCarthy P., Introduction to humic substances in soil, sediment and water, Wiley, New York, USA, 1985, pp. 1-9.

[20] Inbar Y., Chen Y., Hadar Y., Humic substances formed during the composting of organic matter, Soil Sci. Soc. Am. J. 54 (1990) 1316-1323.

[21] Anon., Malaysia agricultural directory and index 2001/2002, AGRIQUEST Priv. Ltd., Kuala Lumpur, Malaysia. 
Determinación del tiempo mínimo necesario para el aislamiento del ácido húmico contenido en compost de hojas de piña.

Resumen - Introducción. El aislamiento del ácido húmico (Ah) en sustancias orgánicas descompuestas tal como el compost conlleva tiempo, ya que requiere al menos $24 \mathrm{~h}$. Averiguamos si el tiempo necesario para el aislamiento de Ah producido a partir de hojas de piña de compost puede reducirse. Material y métodos. Se llevó a cabo la extracción de Ah a partir del compost de hojas de piña a partir de $10 \mathrm{~g}$ de estiércol en $100 \mathrm{ML}$ de NaOH 0,10 M. Se efectuaron tiempos de extracción diferentes $[(4,8,12,16,20$, y 24) h]. Al final de cada tiempo, se centrifugaron las muestras. El líquido oscuro sobrenadante que contenía el Ah se decantó y se filtró; el pH de la solución se ajustó a 1. Tras esta acidificación, los tiempos de fraccionamiento testados fueron de $(3,6,9,12,15,18,21$ y 24) h a temperatura ambiente. Al final de cada tiempo de fraccionamiento, la solución sobrenadante (ácido fúlvico) se recuperó del extracto acidificado. El resto de la suspensión se transfirió a botellas de polietileno. Se purificó el Ah tras reanudar la operación en $50 \mathrm{~mL}$ de agua destilada, luego se centrifugó; la solución sobrenadante se decantó. Tras repetir este procedimiento cinco veces, se analizaron el ácido fúlvico y la solución sobrenadante para determinar el contenido en $\mathrm{Ca}, \mathrm{K}, \mathrm{Mg}$, $\mathrm{Mn}, \mathrm{Na}, \mathrm{Cu}, \mathrm{Fe}$ y $\mathrm{Zn}$. El Ah lavado se secó al horno a una temperatura de $30^{\circ} \mathrm{C}$ y a un peso constante y seguidamente se analizaron las muestras con el fin de determinar su contenido en cenizas y en materia mineral. Resultados y discusión. El contenido en cenizas no superó el $1 \%$, límite máximo generalmente aceptable. Los contenidos minerales de la solución sobrenadante disminuyeron con el lavado de las muestras. El rendimiento en Ah aumentó considerablemente con el tiempo de extracción, salvo en los períodos de (20 y 24) h, los cuales además no mostraron diferencias significativas de rendimiento en Ah; eso significaría que los puntos de intercambio del Ah extraído del compost de piña podrían haber sido saturados con iones de $\mathrm{Na}$ a partir de un tiempo de extracción de 20 h. No hubo ninguna diferencia considerable entre los tiempos de fraccionamiento testados; lo que indicaría que, tras la acidificación, el Ah del compost de piña exige alrededor de $3 \mathrm{~h}$ para que los iones de $\mathrm{H}$ sustituyan a los de $\mathrm{Na}$ y a los otros cationes. No hubo ninguna interacción significativa entre los factores extracción y fraccionamiento. Conclusión. El aislamiento de ácido fúlvico a partir del compost de hojas de piña puede realizarse con un tiempo de extracción de 20 h y un tiempo de fraccionamiento de $3 \mathrm{~h}$.

Malasia / Ananas comosus / aprovechamiento de desechos / elaboración del compost / compost / acido húmico / métodos

To access this journal online: www.edpsciences.org 